\title{
The Mental Health Act Commission
}

\author{
Christopher Curran and William Bingley
}

\begin{abstract}
The aim of this article is to promote a clearer understanding of the Mental Health Commission's development, structure and function. Over recent years, mental health profestionals and patients have become more aware of the organisation and its work, although some may remain uncertain obout its function and how it itis into the overall care of detained patients. The Commiselon's fundamental job is to sofeguard the wellbeing and interests of patients detained under the Act. Its remit does not extend to informal patients. Unless otherwise indicated, all statutory references are to the 1983 Mental Health Act.
\end{abstract}

\section{Historical perspective}

From the 18th century, special bodies have existed to monitor the use of statutory powers and ensure that mentally disordered people receive appropriate care. Early forerunners of the Mental Health Act Commission were the Commissioners in Lunacy, established in 1774 under the Act for Regulating Private Madhouses. Under the Mental Deficiency Act (1913), the Commissioners for Lunacy were reconstituted as the Board of Control and were further reorganised under the Mental Treatment Act of 1930. The Board of Control was dissolved in 1960 with the implementation of the 1959 Mental Health Act. Its statutory duties were distributed among a number of new organisations, e.g. the Mental Health Review Tribunals were given the power to discharge detained patients. Some patients continue to think that Commissioners have the power to discharge them. Between 1959 and 1983 there was no equivalent to the current Commission. Two principal factors influenced its re-creation. First, a number of inquiries into abuses and poor conditions in psychiatric hospitals in the 1970s and 1980s (Martin, 1984) and second, concerns about the treatment of detained patients without consent (Fennell, 1986).

\section{The Mental Health Act Commission for England and Wales (the Commission)}

Section 121 of the Mental Health Act (1983), and section 11 of the National Health Service Act (1977), imposed a duty on the Secretary of State for Health to establish the Mental Health Act Commission. The Commission was established on 1 September 1983 under the Mental Health Act Commission (Establishment and Constitution) Order (S.I. 1983 No. 892), and started work on 30 September 1983.

\section{Present structure and composition of the Commission}

The Commission is governed by the Mental Health Act Commission Regulations (S.I. 1983 No. 894). It is a special health authority within the National Health Service (Fig. 1) and comprises approximately 90 part-time Commissioners. They are appointed by the Secretary of State for Health for England and the Secretary of State for Wales, usually for four years. Commissioners are drawn from a multi-professional background, and they include lawyers, doctors, nurses, social workers, psychologists, academics, other specialists and lay persons. There is a chairman, vice-chairman, and chief executive. Commissioners tend to offer their services two days a week, working within a specified geographical area. All have a special knowledge and interest in mental health issues. What may not be realised is that Commissioners not only contribute on a part-time basis, but live and work all over England and Wales. For a relatively small organisation, the Commission undertakes a complex range of tasks. Annually the Commission visits 673 hospitals, mental nursing homes and social service departments. Between 19911993 the Commission handled 1,220 complaints and responded to 8,885 requests for second medical (S.58) and other opinions (S.57).

\section{Centralisation of the Commission}

In 1990 the Mental Health Act Commission appointed its first chief executive and centralised its administration in Nottingham. This has enabled the commission to fulfil its statutory duties more effectively and to make an improved contribution at the level of general policy making.

\section{Central Policy Committee (CPC)}

The Commission is governed by the Central Policy Committee whose 12 members are 


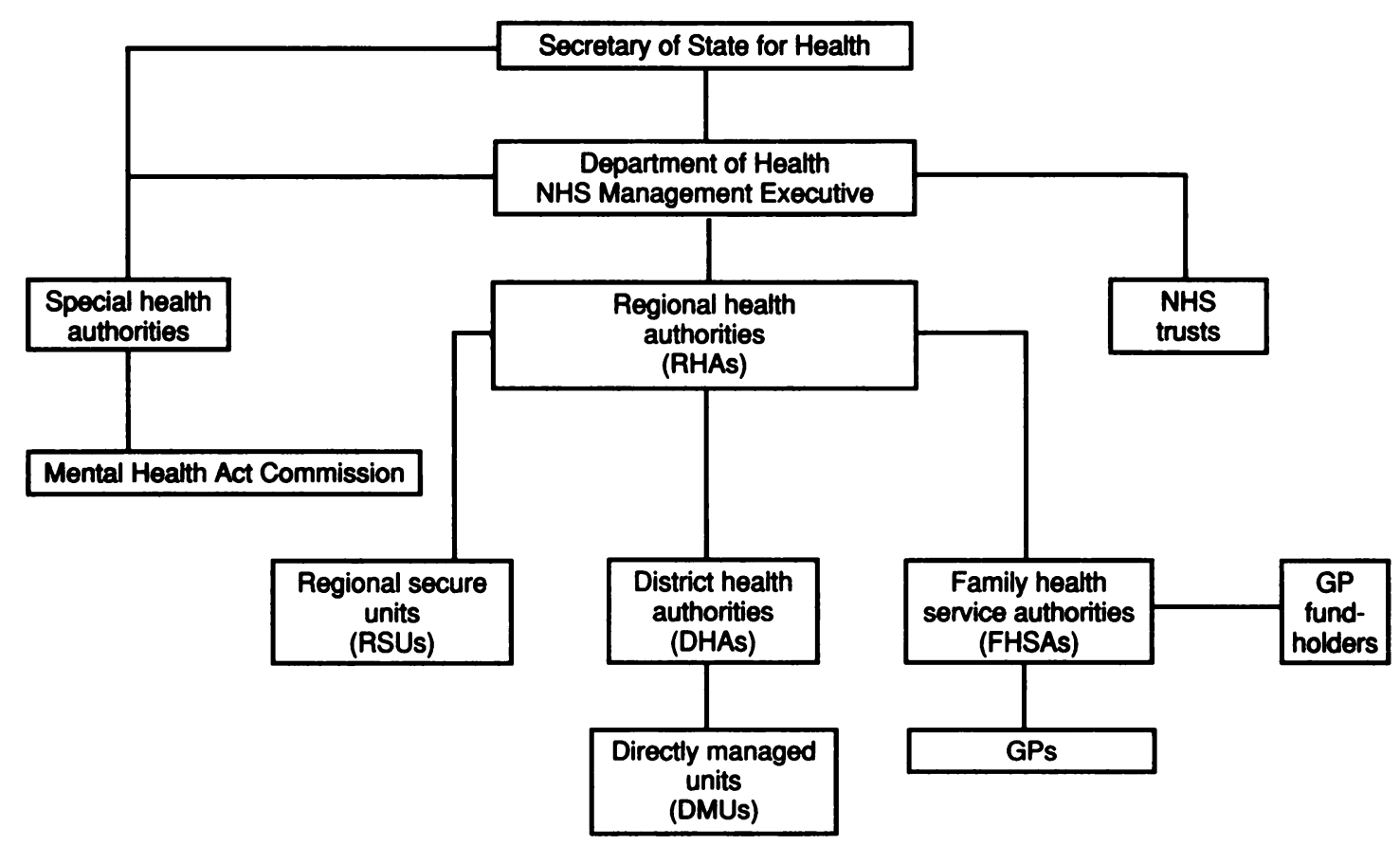

Community health councils (outside the managerial structure)

\section{Fig. 1. The Mental Health Act Commission in relation to the National Health Service}

appointed by the Secretary of State for Health. The CPC has overall responsibility for the activities and financial administration of the Commission.

Commission visiting teams (CVT) and Special hospital panels (SHP)

The Commission is organised into seven commission visiting teams, comprising a number of commissioners who are responsible for all visits and responses to complaints in a specific geographical area. Commissioners are also members of one of three SHPs. Each SHP undertakes the commission's responsibilities in one of the three special hospitals. Each team is led by an experienced commissioner (Fig. 2).

\section{National standing committees (NSC)}

There are nine national standing committees, dealing with specific policy and practice areas (Fig. 2). Commissioners may also be a member of at least one NSC.

\section{Mental health policy and practice}

Whereas the primary focus of the Commission's work is to ensure that the rights of detained patients are protected, the Commission also comments on the services that detained patients receive (Table 1). Consequently the Commission within the context of its statutory duties attempts to influence both current mental health service delivery and future policy development. It has recently commenced the issuing of practice notes which offer advice on issues of good practice under the Mental Health Act (1983). The first of these relate to:

(i) the administration of clozapine and other treatments requiring blood tests

(ii) nurses, and the administration of medicine for mental disorder

(iii) section 5(2) of the Act and transfers.

\section{Complaints}

A major function of the Commission is to investigate complaints. Each complaint is dealt with by experienced Commissioners. Section 120 (1)(b) imposes a duty "to investigate":

(i) "any complaint made by a person in respect of a matter that occurred while he was detained under this Act in a hospital. . and which he considers has not been satisfactorily 
Chairman \& Vice-Chairman

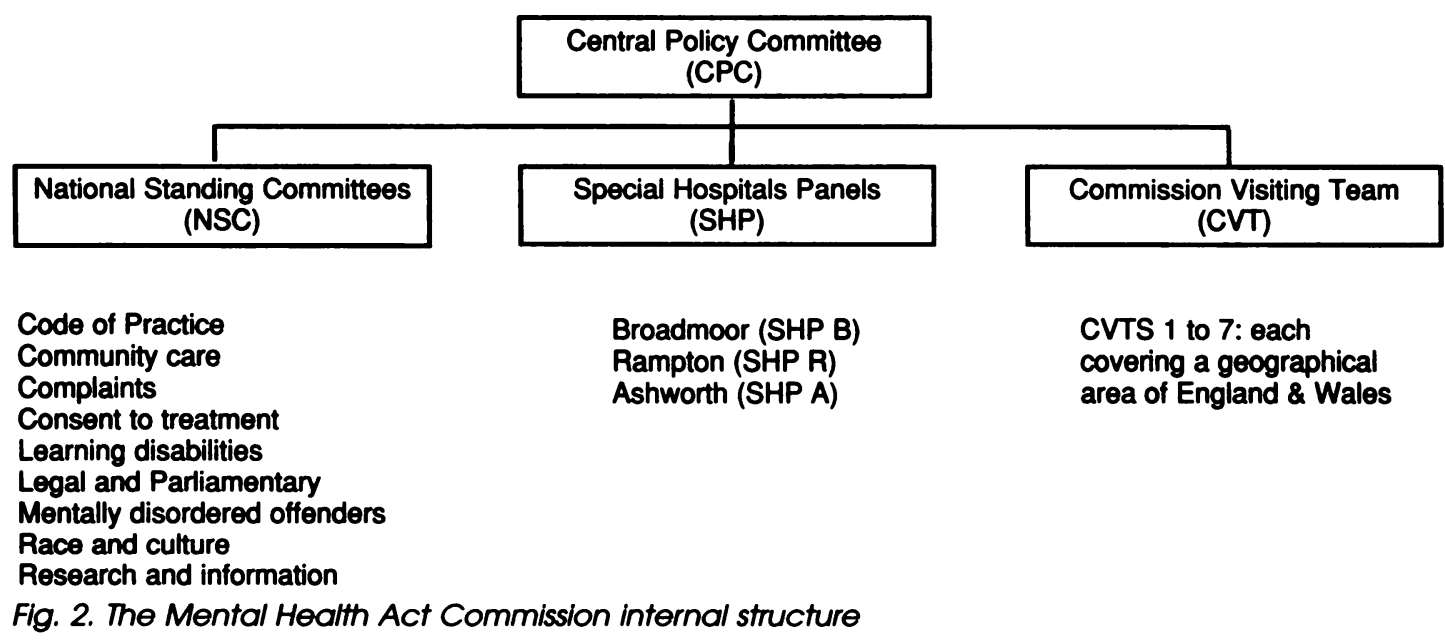

dealt with by the managers of that hospital or mental nursing home"; and

(ii) "any other complaint as to the exercise of the powers or the discharge of the duties conferred or imposed by this Act in respect of a person who is or has been so detained."

If a Member of Parliament requests the Commission to investigate a complaint within their remit, it has a duty [S 120(3)] to report directly back to him or her. Patients have recourse to the Health Service Commissioner if they are not satisfied with the way their complaint has been handled.

In the light of the Report of the Committee of Inquiry into Complaints about Ashworth Hospital (1992), some may question whether the Commission has been as effective as it might have been. The Commission acknowledges this view and the report's recommendation that the Commission withdraws from investigating complaints. It has concluded, however, that it would not be right to accept this recommendation. The Commission feels that its existing complaints jurisdiction should be enhanced. As hospitals, mental nursing homes and social services authorities continue to improve their own response to complaints, the number filtering through to the Commission should gradually reduce.

\section{Visiting}

Section 120 (1)(a) of the Act imposes a duty on the Commission to "... visit and interview in private patients detained under this Act in hospitals and mental nursing homes". The Commission visits all psychiatric hospitals and mental nursing homes providing care for detained patients at least once a year. Special hospitals are visited every two months and regional secure units every six months. Despite the fact that at any one time approximately $5 \%$ of psychiatric in-patients are detained, most are likely not to

Table 1. The Commission's statutory and other duties

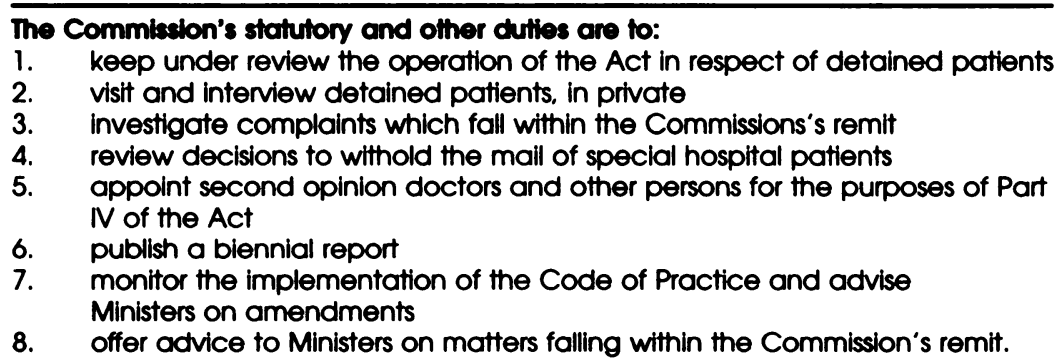


have a chance to raise their potential concerns with Commissioners. This is because their average stay is thought to be approximately 21 days and is unlikely to coincide with a Commission visit. Perhaps less than 20\% of such patients have therefore been seen by a Commissioner.

\section{Ethnic minority issues}

The Commission is constantly aware of the importance and sensitivity of this aspect of psychiatric care. There is a perception from consumers that ". . . it is rare for staff to show real understanding of institutional racism that affects black people and the cultural differences in illness presentation" (5th Biennial Report 1993). The membership strives to reflect the ethnic and gender composition of society; $9 \%$ of Commissioners come from ethnic minority backgrounds. and $45 \%$ are women.

\section{Staff concerns}

In the first instance, NHS staff should ordinarily raise any concerns about the care of detained patients through their local procedures. If their concerns remain unresolved they "... may be able to refer the matter to ..." the Commission (para 25, NHSME, EL 193]51).

\section{Code of Practice}

Section 118 of the Act imposes a duty on the Secretary of State for Health to prepare a Code of Practice and the code was published in 1990 with a revised edition in 1993 (effective 1 November). Although it is intended, primarily, for detained patients, much of its content is equally applicable to informal patients. The code provides detailed guidance on good practice in the care and management of psychiatric patients and how the Act should be implemented. Most professionals now consult the code. The code is constantly monitored by the Commission and from time to time it makes suggestions for amendment to the Secretary of State.

\section{Appointment of second opinion appointed doctors (SOAD) and other persons under Part IV of the Act}

The Act imposes a duty on the Commission (S. 121 [2)(a]) to appoint:

(i) registered medical practitioners, to provide second opinions under S. 58 of the Act, in relation to ECT and medication. The Commission responds to 4,000 requests each year. As Gittleson (1993) suggests, for psychiatric professionals the SOAD represents the most frequent contact with the public face of the Commission; and (ii) other persons, who are lay persons and experienced health professionals (not doctors), in relation to certifying a patient's consent to treatment under $S 57(2)(a)(b)(3)$ regarding psychosurgery and hormone treatment.

There were 65 referrals to the Commission (1989-1991) under section 57 for psychosurgery and certificates were issued for 56 patents. Figures for 1991-1993 reveal a drop to 46 referrals with 42 certificates issued.

\section{Monitoring of decisions}

All complaints and second opinions, i.e. provided under S. 57 and S. 58, are audited on a regular basis.

\section{Biennial report}

Section 121 (10) of the Act, requires the Commission to ". . . publish a report on its activities ..." for Parliament. The reports contain a description of the Commission's activities and comments on current mental health policy and practice.

\section{Legal advice}

The Commission receives a considerable number of telephone requests for practice advice, frequently involving complex legal issues. The Commission has no statutory right to give formal legal advice to professionals. It can simply offer an opinion based on the limited information received at that time. The Commission should not be consulted as an alternative to obtaining formal legal advice. Subject to this proviso, if a Commission view is still required, it should be requested in writing. This may take more time but allows a more considered response.

\section{Conclusion}

The Commission's main function is to protect the rights of detained patients and make a contribution ensuring that they receive a good quality of care and treatment. Its creation resulted from a common concern that individuals who are mentally ill or learning disabled may be vulnerable (Murphy, 1990). There is a constant need to ensure that their care is warranted, does not fall below professionally acceptable standards of practice and that patients are protected from unnecessary or ill treatment. Health care professionals have to address the fine balance between the rights of the individual and the wider interests of society when considering whether a vulnerable person needs care and treatment in the absence of giving consent.

The Commission is reviewing its current role with a view to targeting its resources more effectively. It is considering the value of having some 
full-time, as well as some part-time Commissioners, and a more locally focused service. It hopes to undertake more unannounced visiting and to more effectively target areas that cause concern. Where there is blatant bad practice primarlly in relation to the Act, the Commission is considering the use of a Commission notification procedure. If not complied with, this could lead to inclusion in the Biennial Report.

Any just system of caring for detained patients must ensure their views are heard, that decisions about them are made in their best interests, and that professionals are able to justify such decisions. The Commission will continue to strive to make an increasingly effective contribution to the achievement of this objective.

\section{Acknowledgement}

We would like to thank Mr Brian Smith, Mental Health Act Commissioner from 1983 to 1993, for his valuable comments.

\section{References}

FEnNeu, P. (1986) Law and psychlatry. Journal of Law and Soclety. 13, 35-65.

Grmueson, N. (1993) A Second Opinion Doctor's View. Internal Commission Paper.

MARTn, J.P. (1984) Hospttals in Trouble. Oxford: Bastl Blackwell.

Mental HEAlth Act Commission (1993) Fyth Blennial Report 1991-1993. London: HMSO.

MURPHY, E. (1990) The Mental Health Act - and what is not in it. In Current Approaches-Psychiatry and the Law. London: Duphar Medical Relations.

NHS MANAGEMENT EXECUTIVE (1993) Guidance for Staff on Relations with the Public and the Media. 8 June. EU93)51.

Report of the Committee of Inquiry into Complaints about Ashworth Hospttal, Volumes I \& II (1992) London: HMSO.

Report of the Review of Rampton Hospttal (1980) Cmnd.8073. London: HMSO.

Christopher Curran, Patients Councll/Aduocacy Co-ordinator; and William Bingley, Chief Executive, the Mental Health Act Commisston, Nottingham

\section{Complaints about Mental Health Act Commission visits}

A recent complaint by a Member of the College on the methods of a visiting team of Mental Health Act Commissioners to investigate a section 2 detention resulted in an apology to the psychiatrist "for the manner in which the matter was handled on the day". The Commission have expressed the wish to be informed of similar instances in which their visitors have been felt to have acted inappropriately or insensitively towards patients or staff. In such a case, the complaint should be referred to $\mathrm{Mr} \mathrm{W}$. Bingley, Chief Executive of the Mental Health Act Commission. Maid Marian House, Hounds Gate, Nottingham NG1 6BG. 